\section{Seliverstov V., Boichuk V., Dotsenko V., Kuzmenko $\mathbf{V}$.}

\title{
STABILITY ASSESSMENT OF 30XHMЛ STEEL MELTING PROCESS IN ELECTRIC ARC FURNACES ON THE BASIS OF TECHNOLOGICAL AUDIT OF SERIAL MELTINGS
}

Об’єктом дослідження є процес плавки сталі ЗоХНМЛ в двох електродугових печах місткістю 6 тонн. Технологічний аудит процесу здійснювався на діючих печах в сталеливарному цеху машинобудівного підприємства, який спеціалізується на виготовленні великого фасонного лиття для виробів транспортного машинобудування. Аудит мав на меті аналіз відповідності виконуваних основних технологічних операцій плавки необхідним регламентованим технологічним інструкціям.

На основі проведення серійних плавок отримана вибірка експериментально-промислових даних по визначенню межі мічності зразків сталі ЗОХНМЛ. Встановлено, що за реальними виробничим даними серійних плавок неможливо постулювати закон розподілу, зокрема, говорити про нормальний розподіл. Тому використання статистичних вибіркових функцій для оцінки стабільності плавки недоцільно. В якості

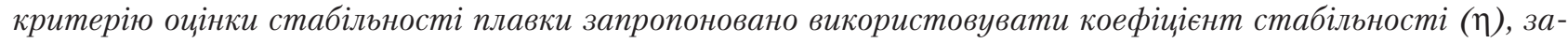
снований на розрахунку ентропї (H). Запропоновано для практичного застосування в оцінці стабільності плавки використовувати нечіткий опис цих величин. В цьому випадку можна прийняти, що розраховані значення ентропії $і$ коефічієнта стабільності плавки для кожної вибірки окремо $і$ загальної вибірки формують ліву $\left(\alpha_{j p}\right)$ і праву $\left(\beta_{j p}\right)$ межу нечіткості. Запропоновано в нечіткому описі використовувати функцї приналежності $(L-R)$ типу. У конкретному випадку можна прийняти, що $\alpha_{j p}=2,63, \beta_{j p}=2,71$ (для нечіткого числа H) $i \alpha_{j p}=0,22, \beta_{j p}=0,24$ (для нечіткого числа $\eta$ ).

Завдяки запропонованому способу оцінки стабільності плавки забезпечується можливість отримання об'єктивних даних, не покладаючись на припущення про нормальний закон розподілу. Запропонований спосіб інваріантний типу технологічного процесу в заготівельному виробництві. Це можуть бути процеси обробки металів тиском, термічної обробки та інші металургійні процеси. Важливість запропонованого способу пов'язана з тим, що якість подальших технологічних операцій для отримання готових деталей залежить від успадкування якості заготівельного виробництва як попередніх технологічних етапів виробництва продукції.

ключові слова: електродугова піч, плавка сталі, коефіцієнт стабільності плавки, функція приналежності, нечітке число, межа нечіткості.

\section{Introduction}

Steel melting in electric arc furnaces is one of the processes that have significant uncertainty, which manifests itself in relation to both input and output process variables. The input variables traditionally include the content of elements of the chemical composition of steel, and the output properties are the mechanical properties of the finished steel. Uncertainty is two-level and is manifested in the assessment of the modal value and compactness of the body of uncertainty, knowing that it is possible to solve the clustering problem to obtain the functional dependence of mechanical properties on the chemical composition [1,2]. However, it is important to set the left and right boundaries of fuzziness, regarding the choice of which expert opinions may differ. The values of these limits can be determined only on the basis of real data, which are available in the mode of carrying out serial heats.

Therefore, it is relevant to conduct a technological audit of such heats. Due to this, it is possible to obtain a sample of real data for further evaluation of the inaccuracy of the description of technological parameters of melting in electric arc furnaces and to assess the stability of this process.

\section{The object of research and its technological audit}

The object of research is the process of 30ХНМЛ steel melting in two electric arc furnaces with a capacity of 6 tons. Technological audit of the process is carried out on existing furnaces in the steel foundry of a machine-building enterprise specializing in the manufacture of large shaped castings for products of transport engineering. The audit is aimed at analyzing the compliance of the performed main technological melting operations with the required regulated technological instructions. In the course of melting, in accordance with the regulations, samples are taken to determine the mechanical properties of steel 30ХНМЛ. Serial observations are carried out for 120 days.

Based on it, the following is established. 
The first period of melting is carried out at the maximum power of the transformer, the connection of the winding of which is included in the triangle mode. At this point, the first half of the melting consists of almost continuous short circuits and current surges. Melting of the charge begins from the top and as the metal is melted and the electrodes are lowered deep into the mixture, it spreads to the underlying layers. When melted, the metal flows down between the pieces of the charge, heats them and gradually forms a bath of liquid metal at the bottom of the furnace. At the first stage, three wells are melted under each electrode in the charge, which are then connected into one common well. At this stage, the transformer is switched to low power mode, in order to prevent thermal wear of the lining by the opened arcs.

The oxidation period begins with the fact that after the formation of slag, carefully mixing, take the first sample of steel to determine the rapid analysis of the content of carbon, manganese, phosphorus, sulfur and chromium. For deoxidation of liquid steel, direct introduction of deoxidizers, as well as ferromanganese in the amount of $0.4-0.5 \%$ of the mass of steel is performed, and then in 3-5 minutes - ferrosilicon. 2-3 minutes before steel production, the remaining amount of ferromanganese and aluminum is introduced. Slag deoxidation in the existing conditions of the workshop is carried out until the slag sample after cooling has a light green or blue color at the break.

\section{The aim and objectives of research}

The aim of research is determination the stability indicators of 30ХНМЛ steel melting according to the quality criterion «tensile strength» taking into account the uncertainty.

To achieve this aim it is necessary to solve the following objectives:

1. To obtain a sample of primary data on the determination of the tensile strength of 30ХНМЛ steel samples in serial melting.

2. To choose and justify the criteria for assessing the melting stability.

3. To carry out a comparative analysis of the calculation of melting stability indicators, justifying the method of its description expedient for practical use.

\section{Research of existing solutions of the problem}

The problem of assessing the stability of electric arc melting processes is reduced to the choice of evaluation criteria and the possibilities of their application in accordance with the level of technological development in a particular production. Typical solutions in this part are the presentation as priority electrical modes of operation of the furnaces as energy technology complexes integrated into the power grid $[3,4]$ or thermal performance [5]. In the first case, the actual modeling and parameter estimation is replaced by a computer using ready-made software packages, for example, in the SIMULINK/MATLAB environment [3]. In the second case, $3 \mathrm{D}$ modeling is used to estimate thermal fields, temperature distribution in the furnace depending on the internal geometry, systems for isolating its individual elements and cooling [5]. Such typical approaches are convenient, given the current capabilities of software and hardware, but they are focused more on the performance of the metallurgical units themselves, rather than on the products manufactured by them. A certain development of the evaluation criteria of the technological component can be found in [6-8]. Thus, in [6], the formation of estimated technological parameters is considered from the standpoint of the study of metallurgical processes occurring in a furnace. And in [7, 8], it is proposed to consider economic criteria as criteria for evaluating the melting efficiency. Finally, an approach based on the construction of functional dependences of properties on the chemical composition formed at the stages of melting and modifying [9] is also common. Technological priorities in assessing the stability of melting, understood as an analogue of the efficiency of the process, should be organically combined with indicators of metallurgical aggregates. Such mutual integration allows implementing solutions in the field of automated or automatic control of melting [10, 11]. And also to use the solutions obtained for evaluating measures for the technical re-equipment of melting sections of workshops [12]. All this allows to conclude about the importance of the choice of performance indicators and criteria for assessing the stability and efficiency of melting processes. At the same time, noting the indisputable advantages of modern computer simulation tools, it should be noted that it is impossible to do without real industrial data and conducting experimental and industrial research in mass production.

\section{Methods of research}

The results of determining the strength limit provided by the laboratory were processed by the methods of mathematical statistics. The expected value, variance and standard deviation were calculated. To determine the stability of the melting process, the concept of entropy was used, by analogy with that used in information theory. Entropy was calculated as a function of the probability of observing a specific value of the ultimate strength of steel $\left(x_{i}\right)$ in a given melting and the logarithm of the selected basis of the probability of observation [13]:

$$
H=-k \sum_{i=1}^{n} P\left(x_{i}\right) \log P\left(x_{i}\right)
$$

where $k$ - some positive constant; $P\left(x_{i}\right)$ - probability of observing $x_{i}$ values.

The stability of the melting process when used as an estimate of the entropy was estimated as follows:

$$
\eta=1-H_{\max }^{-1} H
$$

where $H$ - the entropy corresponding to a given distribution of the values of the ultimate strength of steel in the $i$-th melting; $H_{\max }$ - the maximum possible entropy corresponding to a uniform distribution; $\eta$ - stability of the melting process.

Formula (2) is applicable in the case of a single-mode distribution of a random variable characterizing the melting process.

\section{Research results}

The results of determining the strength limit provided by the laboratory for the period of the technological audit are shown in Fig. 1. 


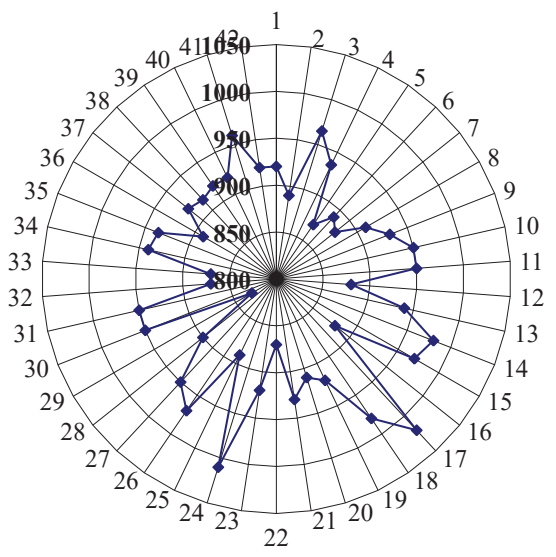

Fig. 1. Experimental data on the value of the ultimate strength $\sigma_{b}$ of 30XHMЛ steel in serial meltings

(the numbers of meltings are indicated on the periphery of the pie chart, the values of $\sigma_{b}, \mathrm{MPa}$ are indicated on the ordinate axis)

Fig. 2 shows a histogram of the distribution of the $\sigma_{b}$ value, based on a total sample of experimental industrial data.

From Fig. 2 it is possible to see that the distribution of data indicates the probable presence of a systematic error, manifested in the presence of more than one vertex. This means that the sample may be heterogeneous. This situation is possible, since the melting is carried out in two different furnaces and in different conditions. To verify this, the original sample was artificially divided into two, each of which, presumably, described the distribution of data on the furnaces. Given the complexity of unique identification, expert opinion was used. Fig. 3, $a, b$ are histograms obtained after splitting the initial sample.

The results of the calculations of the entropy and the stability coefficient of melting are given in Table 1. From Fig. 3 it follows that the partitioning of the sample gave the best result in estimating the entropy and melting stability coefficient, and the result for samples No. 1 and No.2 turned out to be almost the same.

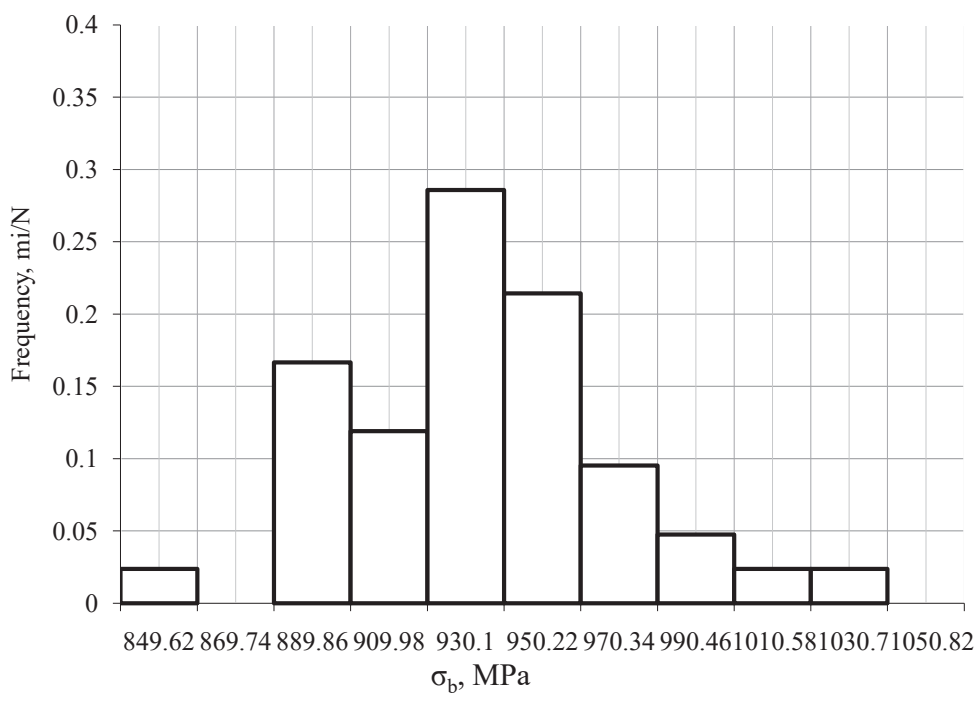

Fig. 2. The histogram of the $\sigma_{b}$, distribution, built on the total sample
The results of entropy calculations of the strength limit of steel $\sigma_{b}$ and the stability coefficient of melting

\begin{tabular}{|c|c|c|}
\hline Calculated parameters for samples & $H$, bit & $\eta$ \\
\hline Total sample & 2.706365 & 0.217685 \\
\hline Sample No. 1 & 2.630827 & 0.23952 \\
\hline Sample No.2 & 2.647708 & 0.234641 \\
\hline
\end{tabular}
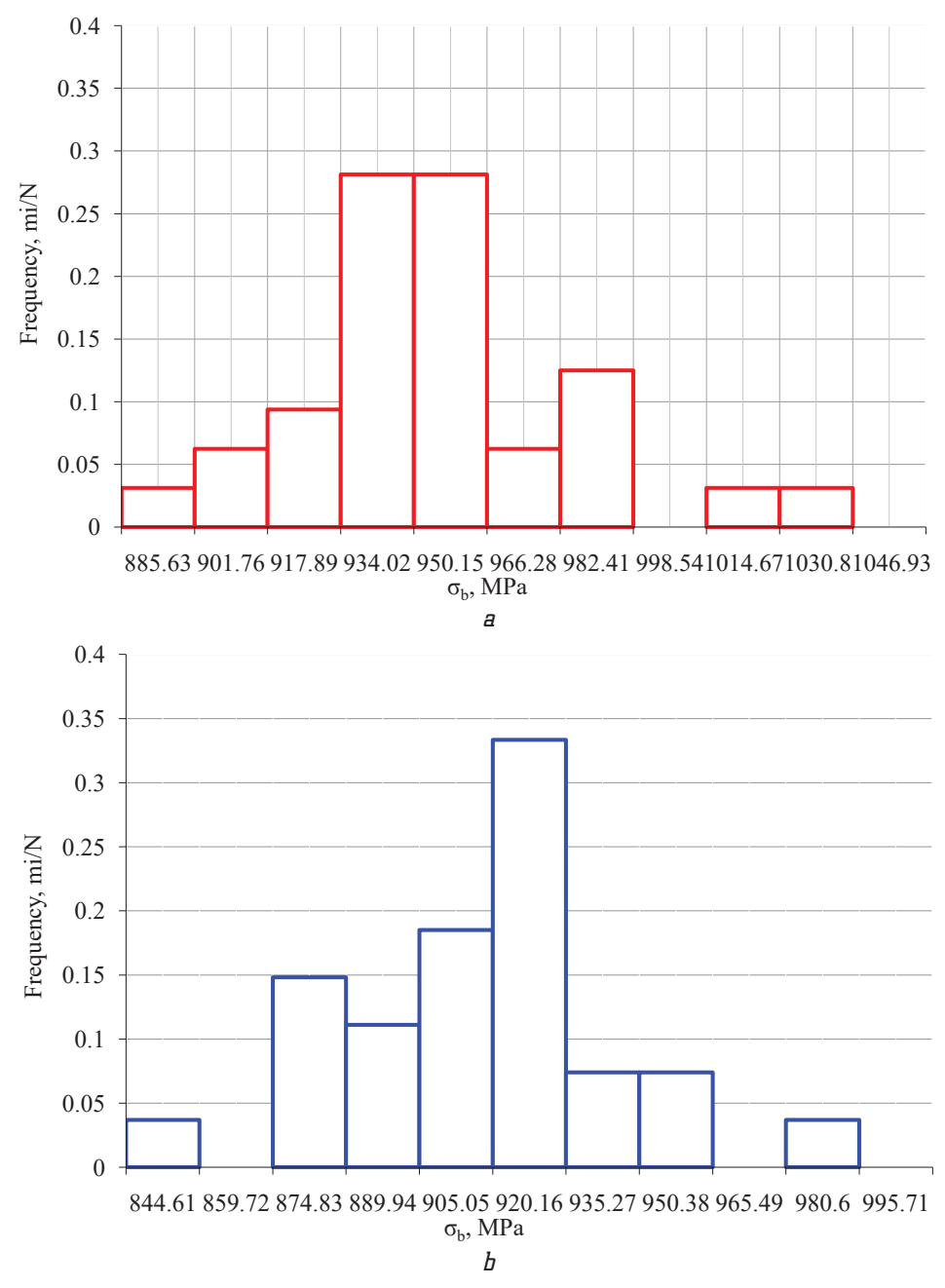

Fig. 3. $\sigma_{b}$ distribution when splitting the sample: $a$ - sample No. $1 ; b$ - sample No. 2

However, the problem in estimating the distribution parameters remained. Therefore, it is impossible to talk about the distribution density and it is more expedient to present the ultimate strength as a fuzzy value. At the same time, the output variable is a fuzzy number $F_{j p}$, described by membership functions $(L-R)$ of the type [1]:

$$
\mu\left(F_{j p}\right)= \begin{cases}L\left(\frac{\bar{F}_{j p}-F_{j p}}{\alpha_{j p}}\right), & F_{j p} \leq \bar{F}_{j p}, \\ R\left(\frac{F_{j p}-\bar{F}_{j p}}{\beta_{j p}}\right), & F_{j p}>\bar{F}_{j p},\end{cases}
$$

where $\bar{F}_{j p}$ - the measured value of the output variable, in the $j$-th experiment, which is modal for a fuzzy number $F_{j p}, j=1,2, \ldots, n, p=1,2, \ldots, m$; 
$\alpha_{j p}, \beta_{j p}-$ the left and right fuzziness coefficients in the description (3).

Similarly, in the form of (3), the stability coefficient can be represented, which also appears as a fuzzy number. In this case, it can be assumed that the calculated values of entropy and melting stability coefficient for each sample separately and the total sample form the left and right fuzziness boundary in the description (3). In a specific case, it can be assumed that $\alpha_{j p}=2.63, \beta_{j p}=2.71$ (for a fuzzy number $H$ ) and $\alpha_{j p}=0.22, \beta_{j p}=0.24$ (for a fuzzy number $\eta$ ).

\section{SWOT analysis of research results}

Strengths. The strength of this research is the justification of the method for assessing the stability of the electric melting of 30XНMЛ steel. This is due to the importance of the quality issues of finished products, on which the competitiveness of the manufacturing company fully depends. The inability to ensure the specified indicators of steel quality stability for the selected indicators may be due to the lack of understanding of rational ways to implement the organizational and technological measures of the melting company. In turn, this understanding should be based on sound assessments of quality criteria. Thanks to the proposed assessment methods based on the use of the concepts of entropy and the stability coefficient, this possibility is provided. It should also be noted that the proposed method of assessing the stability indicators is invariant to the type of technological process in the blank production. These can be metal processing, pressure, heat treatment and other metallurgical processes. This is explained by the fact that the quality of further technological operations for the production of finished parts depends on the inheritance of the quality of the blank production as the previous technological stages of production.

Weaknesses. The weak points of this research are related to the fact that conclusions about the numerical values of the fuzziness boundaries in the description of entropy and the stability coefficient of melting are made from a small sample of data. This can lead to the fact that in the assessment of real data in terms of serial heats inaccuracies are possible. The consequence of this may be an inaccurate assessment of the membership function and overestimated or underestimated melting stability. This, in turn, can lead to erroneous organizational and technological solutions and associated costs.

Opportunities. Additional opportunities when using the above results in an industrial environment are associated with the conduct of serial heats and the accumulation of data to form a more representative sample. The result of this may be a refinement of calculations for the lower and upper boundaries of fuzziness, the modal value and compactness of the body of entropy uncertainty and the coefficient of melting stability. The more accurate values obtained in this way will provide a more accurate description of the membership function, which can be used to assess the efficiency of the electric arc melting process. It should be noted that the effectiveness here refers to the compliance of the actual entropy indicators and the stability coefficient with the specified values.

Threats. Obvious threats when using the obtained results are associated with the requirement of reproducible results. This, in turn, requires the maintenance of strictly regulated values of the content of chemical elements in steel. Attempting to use the research results without a prior technological audit of specific melting conditions in its production can lead to inadequate results. In this case, there will be the problem of estimating the real indicators of its steelmaking production, which can be either overestimated or underestimated. Elimination of such risks requires prior adaptation of the results obtained in this research to the specific conditions of its production.

\section{Conclusions}

1. On the basis of carrying out serial meltings, a sample of experimental and industrial data is obtained to determine the tensile strength of 30ХНМЛ steel. As follows from the obtained results, it is impossible to postulate the distribution law, in particular, to speak about the normal distribution. The resulting two-vertex histogram suggests that there is heterogeneity of data, in particular, possible systematic error. Therefore, it is advisable to split the sample into two, in accordance with the regulation of melting in two electric furnaces.

2. As a criterion for assessing the melting stability, it is proposed to use a stability coefficient based on the calculation of the entropy and determined on the basis of a sample of data obtained in the serial melting mode. This allows to remove the strict requirement of compliance with the distribution law to a normal one, on the basis of which the standard deviation can be used as an estimated indicator of melting stability.

3. It is proposed to use fuzzy description of entropy and stability coefficient for practical use in assessing the melting stability. This is justified by the fact that a strict requirement is removed that the distribution law is normal, since the actual distribution density is absent. Despite the fact that this result is obtained for one technology of melting of one steel grade, a similar situation is likely to occur in other industrial conditions. Therefore, it is proposed in the fuzzy description of entropy and melting stability coefficient to use the calculated values of these indicators for the total and divided samples as the lower and upper limits of fuzziness.

\section{References}

1. Domin D. A. Artificial orthogonalization in searching of optimal control of technological processes under uncertainty conditions // Eastern-European Journal of Enterprise Technologies. 2013. Vol. 5, Issue 9 (65). P. 45-53. URL: http://journals.uran.ua/ eejet/article/view/18452/16199

2. Domin D. A. Mathematical modeling in the problem of selecting opti-mal control of obtaining alloys for machine parts in un-certainty conditions // Journal of Mechanical Engineering. 2013. Vol. 16, Issue 6. P. 15-23. URL: http://journals.uran.ua/ jme/article/view/21309

3. Bhonsle D. C., Kelkar R. B. Analyzing power quality issues in electric arc furnace by modeling // Energy. 2016. Vol. 115 P. 830-839. doi: http://doi.org/10.1016/j.energy.2016.09.043

4. Trufanov I. D., Chumakov K. I., Bondarenko A. A. Obshheteoreticheskie aspekty razrabotki stokhasticheskoy sistemy avtomatizirovannoy ekspertnoy otsenki dinamicheskogo kachestva proizvodstvennykh situatsiy elektrostaleplavleniya // EasternEuropean Journal of Enterprise Technologies. 2005. Vol. 6, Issue 2 (18). P. 52-58.

5. Parametric study of heat transfer in an electric arc furnace and cooling system / Khodabandeh E. et. al. // Applied Thermal Engineering. 2017. Vol. 123. P. 1190-1200. doi: http://doi.org/ 10.1016/j.applthermaleng.2017.05.193

6. Metallurgiya plavki chuguna v dugovoy pechi / Grachev V. A. et. al. // Liteynoe proizvodstvo. 1988. Issue 2. P. 19-21. 
7. Shumikhin V. S., Grachev V. A. Tekhniko-ekonomicheskoe sravnenie protsessov plavki chuguna // Liteynoe proizvodstvo. 1988 Issue 2. P. $15-17$

8. Khrapko S. A. Optimizatsiya rezhima vedeniya plavki stali v dugovoy staleplavil'noy pechi po pribyli predpriyatiya // Sovremennaya elektrometallurgiya. 2003. Vol. 2. P. 37-40.

9. Domin D. A., Pelikh V. F., Ponomarenko O. I. Complex alloying of grey cast iron // Liteinoe proizvodstvo. 1998. Vol. 10. P. $18-19$.

10. Razzhivin A. V., Sagayda I. M. Informatsionnoe obespechenie sistemy avtomaticheskogo upravleniya dugovoy staleplavil'noy pech'yu po temperature metalla // Visnik SUDU. 2000. Issue 3 (25). P. 215-220.

11. Domin D. A. Synthesis process control elektrodugovoy smelting iron // Eastern-European Journal of Enterprise Technologies. 2012. Vol. 2, Issue 10 (56). P. 4-9. URL: http://journals.uran.ua/ eejet/article/view/3881

12. Domina O. B. Optimal strategy with technical re-manufacture of basic metals // Technology Audit and Production Reserves. 2011. Vol. 2, Issue 2 (2). P. 40-52. doi: http://doi.org/10.15587/ $2312-8372.2011 .4866$
13. Galkin M. F., Krol' Yu. S. Kiberneticheskie metody analiza elektroplavki stali. Voprosy tekhnologii. Moscow: Metallurgiya, 1971. 304 p.

Seliverstov Vadim, Doctor of Technical Sciences, Professor, De partment of Foundry Production, National Metallurgical Academy of Ukraine, Dnipro, Ukraine, e-mail: seliverstovoy@gmail.com, ORCID: http://orcid.org/0000-0002-1916-625X

Boichuk Viktoria, Department of Foundry Production, National Technical University «Kharkiv Polytechnic Institute», Ukraine, e-mail: litvo11@kpi.kharkov.ua, ORCID: http://orcid.org/0000-00033673-8878

Dotsenko Vadym, PhD, Associate Professor, Department of Technology and Management of Foundry Processes, Odessa National Polytechnic University, Ukraine, ORCID: http://orcid.org/0000-0002-8400-0491

Kuzmenko Victor, PhD, Professor, Department of the Treatment of Metals by Pressure, National Technical University «Kharkiv Polytechnic Institute», Ukraine, ORCID: http://orcid.org/0000-0001-5149-677X

\section{Dotsenko Y., Dotsenko N., Tkachyna Y., Fedorenko V., Tsybulskyi Y.}

\section{OPERATION OPTIMIZATION OF HOLDING FURNACES IN SPECIAL CASTING SHOPS}

Об’єктом дослідження є плавильно-заливальна система иехів спечіальних видів лиття. Процес розглядався на основі імітащійного моделювання потреби кокільних машин або машин лиття під тиском в розплаві і можливостей плавильних і роздавальних печей забезпечити ияю потребу. Моделювання здійснювалося на основі типових рішень по застосовуваних марках печей для виготовлення алюмінієвих сплавів в кольороволиварних цехах машинобудівного підприємства, що спеціалізується на виготовленні лиття в металеві форми для виробів машинобудування.

В результаті імітаційного моделювання отримано опис впливу інтенсивності заявок на розплав з боку кокільних машин або машин лиття під тиском, $і$ часу виконання цих заявок на сумарні витрати по реалізацї технологічного процесу. Запропоновано сумарні витрати визначати як суму витрат, пов'язаних з витратою технологічної електроенергї, i витрат, пов'язаних з імовірним простоєм машин через брак металу. Причому друга складова відображає вимоги до продуктивності машин в умовах реальної їх експлуатації. Тому сумарні витрати на реалізацію прощесу кокільного лиття або лиття під тиском в частині, що стосується узгодженості роботи елементів плавильно-заливальної системи, обрані в якості критерію оптимізації ї функиіонування.

Запропоновано плавильно-заливальну систему розглядати як систему масового обслуговування (СМО) з відмовами. Таке уявлення є найбільш жорстким з точки зору вимог до забезпечення заданої продуктивності. За допомогою дослідження поверхні відгуку вирішена оптимізачійна задача по узгодженості інтенсивності заявок на розплав і часу їх виконання, що мінімізує сумарні витрати на реалізацію технологічного процесу. Отримано локально-оптимальні технологічні рішення, що дозволяють технологам обирати найбільш раціональні рішення по веденню кампанії плавки з використанням роздавальних печей ємністю 0,16-0,25 т. Такі рішення забезпечать можливість зниження витрат на виготовлення алюмінієвого лиття.

Ключові слова: спеціальні види лиття, лиття під тиском, роздаткові печі, плавильно-заливальна система, система масового обслуговування.

\section{Introduction}

In the conditions of mass production of special casting types in shops with chill machines or injection casting machines, it is necessary to ensure the specified performance. However, it is difficult to organize the process in such a way as to harmonize the quality requirements of the resulting castings. If the decisions on the organization of the process are wrong, there may be additional costs for the process. For example, the overrun of energy carriers or material resources is possible. Therefore, it is important to develop solutions in the field of control of 